\title{
Perencanaan, Penganggaran dan Capaian Target Program Wajib Belajar 12 Tahun : Kasus di Kabupaten Bogor dan Kabupaten Bandung
}

\author{
Bayu Kharisma \\ ${ }^{1}$ Departemen Ilmu Ekonomi, Fakultas Ekonomi dan Bisnis, Universitas Padjadjaran \\ Jl. Dipati Ukur No. 35 Bandung, 40132, Indonesia \\ bayu.kharisma@unpad.ac.id
}

\begin{abstract}
Increasing the status of the nine-year compulsory education program into a twelve-year compulsory education program is a challenge for local governments to make it happen because of the fact that occurred in the field that the education office of Bogor Regency and Bandung District Education Office has not been able to complete the nine-year compulsory education, whereas the program is targeted to be completed in 2008 ago. This proves that the government's performance in realizing the compulsory education program is slow. To realize the twelve-year compulsory education mission required consistency in the preparation of planning and budgeting. Problem that occurs is planning and budgeting in education offices Bogor and Bandung regency is still not consistent because of the difference between programs and budgets between documents with each other. These inconsistencies affect the achievement of the twelve-year compulsory education program has not reached a predetermined target.
\end{abstract}

Keywords: compulsory education program, performance, budgeting. planning, inconsistencies

\begin{abstract}
Abstrak
Meningkatkan status program wajib belajar sembilan tahun menjadi program wajib belajar dua belas tahun merupakan tantangan bagi pemerintah daerah untuk mewujudkannya karena fakta yang terjadi di lapangan bahwa Dinas Pendidikan Kabupaten Bogor dan Pendidikan Kabupaten Bandung belum dapat menyelesaikan wajib belajar sembilan tahun, sedangkan program ini ditargetkan akan selesai pada tahun 2008 lalu. Hal ini membuktikan bahwa kinerja pemerintah dalam mewujudkan program wajib belajar lambat. Untuk mewujudkan misi pendidikan wajib dua belas tahun diperlukan konsistensi dalam persiapan perencanaan dan penganggaran. Permasalahan yang terjadi adalah perencanaan dan penganggaran di dinas pendidikan Kabupaten Bogor dan Kabupaten Bandung masih belum konsisten karena perbedaan antara program dan anggaran antar dokumen dengan satu sama lain. Ketidakkonsistenan ini mempengaruhi pencapaian program wajib belajar dua belas tahun belum mencapai target yang telah ditentukan
\end{abstract}

Kata kunci: program wajib belajar, kinerja, penganggaran, perencanaan, inkonsistensi 


\section{LATAR BELAKANG}

Pembangunan di sektor pendidikan merupakan kewajiban bagi pemerintah untuk meningkatkan kualitas sumber daya manusia khususnya bagi dinas pendidikan. Untuk memaksimalkan pelayanan publik di bidang pendidikan, dinas pendidikan harus memiliki strategi yang baik dalam perencanaan dan penganggaran secara lebih efektif dan efisien. Undang-Undang No 25 tahun 2004 tentang sistem perencanaan pembangunan nasional mengamanatkan bahwa setiap daerah harus menyusun rencana pembangunan daerah secara sistematis, terarah, terpadu, menyeluruh dan tanggap terhadap perubahan, dengan perencanaan jangka pendek, perencanaan jangka menengah maupun perencanaan tahunan. Salah satu upaya pemerintah untuk meningkatkan kualitas sumber daya manusia adalah dengan adanya program wajib belajar.

Sebelumnya pemerintah telah menargetkan program wajib belajar 9 tahun yang harus rampung pada tahun 2008, kemudian dengan adanya peraturan presiden baru, maka adanya pergantian status dari program wajib belajar 9 tahun menjadi program wajib belajar 12 tahun. Hal ini menjadi polemik, pasalnya program wajib belajar 9 tahun belum sepenuhnya tercapai sesuai harapan. Dalam paper ini yang menjadi sorotan adalah mengenai perencanaan dan penganggaran serta sejauh mana pencapaian program wajib belajar 12 tahun di dinas pendidikan Kabupaten Bogor dan dinas pendidikan Kabupaten Bandung.

Dinas pendidikan kabupaten Bogor dan Kabupaten Bandung telah memiliki rencana pembangunan jangka menengah daerah (RPJMD) dan rencana strategis (RENSTRA) yang berisi mengenai visi, misi, strategi, arah kebijakan sampai dengan target pencapaian di akhir rencana. Perbedaannya, kabupaten Bogor menyusun RPJMD 2013-2018 sedangkan kabupaten Bandung menyusun RPJMD 2010-2015. Tetapi keduanya memiliki misi yang sama mengenai perwujudan program wajib belajar 12 tahun. Perbandingan antara misi, tujuan dan arah kebijakan antara kedua terlihat dari Tabel 1 berikut ini. 
Tabel 1. Perbandingan Misi, Tujuan, Arah Kebijakan Program Wajib Belajar 12 Tahun Kab. Bandung Tahun 2010-2015 dan Kab. Bogor Tahun 2013-2018

\begin{tabular}{|c|c|c|c|c|c|}
\hline \multicolumn{2}{|c|}{ Misi } & \multicolumn{2}{|c|}{ Tujuan } & \multicolumn{2}{|c|}{ Arah Kebijakan } \\
\hline $\begin{array}{c}\text { Kabupaten } \\
\text { Bogor }\end{array}$ & $\begin{array}{c}\text { Kabupaten } \\
\text { Bandung }\end{array}$ & $\begin{array}{c}\text { Kabupaten } \\
\text { Bogor }\end{array}$ & $\begin{array}{l}\text { Kabupaten } \\
\text { Bandung }\end{array}$ & $\begin{array}{c}\text { Kabupaten } \\
\text { Bogor }\end{array}$ & $\begin{array}{l}\text { Kabupaten } \\
\text { Bandung }\end{array}$ \\
\hline $\begin{array}{l}\text { Ke } 4 \text { : } \\
\text { Meningkatkan } \\
\text { aksesibilitas dan } \\
\text { kualitas } \\
\text { penyelenggaraan } \\
\text { pendidikan dan } \\
\text { pelayanan } \\
\text { kesehatan }\end{array}$ & $\begin{array}{l}\text { Ke 2: } \\
\text { Meningkatkan } \\
\text { kualitas SDM } \\
\text { (pendidikan dan } \\
\text { kesehatan) yang } \\
\text { berlandaskan } \\
\text { Iman dan takwa } \\
\text { serta } \\
\text { melestarikan } \\
\text { budaya sunda" }\end{array}$ & $\begin{array}{l}\text { Ke } 2 \text { : } \\
\text { Meningkatnya } \\
\text { rata-rata lama } \\
\text { sekolah (RLS) } \\
\text { dan } \\
\text { terwujudnya } \\
\text { wajib sekolah } \\
12 \text { tahun yang } \\
\text { berkualitas } \\
\text { beserta } \\
\text { Sasarannya }\end{array}$ & $\begin{array}{l}\text { Ke 2: } \\
\text { Meningkatnya } \\
\text { kualitas SDM } \\
\text { yang berbudi } \\
\text { pekerti luhur, } \\
\text { berbudaya } \\
\text { sunda dan } \\
\text { berlandaskan } \\
\text { iman dan taqwa }\end{array}$ & $\begin{array}{l}\text { Penyelenggaraan } \\
\text { pendidikan gratis } \\
\text { dasar dan } \\
\text { menengah dalam } \\
\text { rangka penuntasan } \\
\text { Wajar Dikdas } 12 \\
\text { tahun pada tahun } \\
\text { 2018, difokuskan } \\
\text { pada Penyediaan } \\
\text { biaya operasional } \\
\text { proses KBM dan } \\
\text { bantuan } \\
\text { pendidikan dasar } \\
\text { dan menengah } \\
\text { bagi siswa }\end{array}$ & $\begin{array}{l}\text { Fasilitasi } \\
\text { kemudahan bagi } \\
\text { anak-anak usia } \\
\text { sekolah jenjang } \\
\text { SMA/Sederajat, } \\
\text { Peningkatan sarana } \\
\text { prasarana } \\
\text { pendidikan } \\
\text { menengah, } \\
\text { Pemerataan } \\
\text { pelayanan } \\
\text { kelembagaan satuan } \\
\text { penddikan } \\
\text { mengengah dalam } \\
\text { rangka rintisan } \\
\text { wajib belajar } 12 \\
\text { tahun }\end{array}$ \\
\hline
\end{tabular}

Sumber : RPJMD Kab. Bandung (2010-2015) dan Kab. Bogor (2013-2018)

Dalam rangka mewujudkan misi dari dinas pendidikan mengenai wajib belajar 12 tahun tidak terlepas dari permasalahan yang selama ini terjadi yaitu adanya inkonsistensi antara dokumen satu dengan dokumen lain, dalam hal ini adalah RPMJD dan RENSTRA. Inkonsistensi ditunjukan dengan adanya program yang tercantum pada RPJMD tetapi tidak ada dalam RENSTRA. Hal ini membuktikan kurangnya perencanaan dan penganggaran yang matang dan pada akhirnya hal ini akan mempengaruhi pencapaian keberhasilan dari tujuan pembangunan dalam bidang pendidikan yang berkesinambungan.

Inkonsistensi menciptakan pencapaian program tidak sesuai dengan target yang telah ditetapkan, hal ini tercermin dari APK dan APM di Kabupaten Bandung dan Kabupaten Bogor pada tahun 2015/2016 belum mencapai 100\% dan Rata Lama Sekolah masih dibawah 9 tahun sehingga capaian program wajib belajar 9 belum maksimal. Dengan adanya latar belakang masalah tersebut maka tujuan penelitian ini adalah untuk menganalisa perencanaan dan penganggaran serta implikasinya terhadap capaian target program wajib belajar 12 tahun dengan membandingkan antara dinas pendidikan di Kabupaten Bandung dan dinas Pendidikan Kabupaten Bogor. 


\section{KAJIAN LIETRATUR}

Menurut Conyers dan Hills dalam Haryanto (2007), perencanaan adalah "suatu proses yang berkesinambungan", yang mencakup "keputusan-keputusan atau pilihan-pilihan atas berbagai alternatif penggunaan sumber daya untuk mencapai tujuan-tujuan tertentu pada masa yang akan datang”. Menurut Haryanto (2007) langkah perencanaan yaitu :

1. Menetapkan sasaran

2. Merumuskan posisi organisasi pada saat ini

3. Mengidentifikasi faktor-faktor pendukung dan penghambat menuju sasaran

4. Menyusun langkah-langkah untuk mencapai sasaran

Menurut Haryanto (2007) penganggaran merupakan aktivitas mengalokasikan sumber daya keuangan yang terbatas untuk pembiayaan belanja organisasi yang cenderung tidak terbatas. Prinsip dasar anggaran sektor publik (Haryanto,2008) : 1) otorisasi oleh legislatif, 2) Komperhensif, 3) Keutuhan anggaran, 4) nondiscretionary appropriation, 5) periodik, 6) akurat, 7) Jelas, 8) diketahui publik.

Di Indonesia, penganggaran dilakukan dengan menganut sistem anggaran berbasis kinerja sesuai dengan Undang-undang No. 1 tahun 2004 dan Undang-undang No 15 tahun 2004. Hal ini dilakukan karena anggaran berbasis kinerja dianggap mampu meningkatkan efisiensi dan efektifitas pengeluaran dengan hasil yang dicapai melalui informasi kinerja. Mengacu pada Undang-undang No 25 tahun 2004 tentang sistem perencanaan pembangunan nasional, perencanaan terdiri dari 5 jenis yaitu :

1. Rencana Pembangunan Jangka Panjang (RPJPD)

2. Rencana Pembangunan Jangka Menengah Daerah (RPJPD)

3. Rencana Strategis Satuan Kerja Perangkat Daerah (RENSTRA-SKPD)

4. Rencana Kerja Pemerintah Daerah (RKPD)

5. Rencana Kerja Satuan Kerja Perangkat Daerah (Renja-SKPD)

Komponen utama perencanaan adalah anggaran, yang merupakan rencana keuangan untuk masa yang akan datang. Rencana tersebut mengidentifikasi tujuan dan tindakan yang diperlukan untuk mencapainya. Perencanaan meliputi pemilihan serangkaian aktivitas dan spesifikasi bagaimana aktivitas tersebut akan dilaksanakan. Perencanaan merupakan landasan 
dari proses manajemen, tanpa perencanaan tidak akan ada dasar bagi fungsi koordinasi dan pelaksanaan fungsi pengendalian. Anggaran merupakan rencana tertulis dari perusahaan, dengan adanya anggaran maka tiap bagian perusahaan dapat mengetahui apa yang harus dilakukan untuk mencapai tujuan.

Penyusunan anggaran harus berpegang teguh pada prinsip pengelolaan keuangan yang baik dengan memperhatikan akuntabilitas, kejujuran dalam pengelolaan keuangan, value for money dan transaparansi serta pengendalian (Mardiasmo, 2002). Dalam mewujudkan efisiensi dan efektivitas anggaran, dana yang tersedia harus dimanfaatkan seoptimal mungkin untuk meningkatkan kesejahteraan masyarakat. Oleh karena itu, dalam perencaan penganggaran, pemerintah harus memperhatikan tujuan, sasaran, hasil, manfaat, serta indikator kinerja yang ingin dicapai kemudian penetapan prioritas kegiatan dan perhitungan beban kerja serta penetapan harga satuan yang rasional.

Anggaran adalah suatu rencana kuantitatif (satuan jumlah) periodik yang disusun berdasarkan program yang telah disahkan (Nafarin, 2004). Anggaran (budget) merupakan rencana tertulis mengenai kegiatan suatu organisasi yang dinyatakan secara kuantitatif untuk jangka waktu tertentu dan umumnya dinyatakan dalam satuan uang, tetapi dapat juga dinyatakan dalam sautuan barang/jasa. Anggaran merupakan alat manajemen dalam mencapai tujuan. Jadi, anggaran bukan tujuan dan tidak dapat menggantikan manajemen. Dalam penyusunan anggaran perlu dipertimbangkan faktor-faktor sebagai berikut (Nafarin, 2004):

1. Pengetahuan tentang tujuan dan kebijakan umum perusahaan.

2. Data masa lalu.

3. Kemungkinan perkembangan kondisi ekonomi.

4. Pengetahuan tentang taktik, strategi pesaing, dan gerak-gerik pesaing.

5. Kemungkinan adanya perubahan kebijakan pemerintah.

6. Penelitian untuk pengembangan perusahaan.

Dalam penyusunan anggaran perlu diperhatikan perilaku para pelaksana anggaran dengan cara mempertimbangkan hal-hal berikut:

1. Anggaran harus dibuat serealistis mungkin dan secermat mungkin sehingga tidak terlalu rendah atau terlalu tinggi. Anggaran yang dibuat terlalu rendah tidak menggambarkan 
kedinamisan, sedangkan anggaran yang dibuat terlalu tinggi hanyalah angan-angan.

2. Untuk memotivasi manajer pelaksana diperlukan partisipasi manajemen puncak (direksi).

3. Anggaran yang dibuat harus mencerminkan keadilan, sehingga pelaksana tidak merasa tertekan tetapi justru termotivasi.

4. Untuk membuat laporan realisasi anggaran diperlukan laporan yang akurat dan tepat waktu, sehingga apabila terjadi penyimpangan yang merugikan dapat segera diantisipasi lebih dini.

Tidak setiap rencana kerja organisasi dapat disebut sebagai anggaran. Karena, anggaran memiliki beberapa ciri khusus yang memebedakan dengan sekedar rencana (Rusdianto, 2006).

1. Dinyatakan dalam satuan moneter

Penulisan dalam satuan moneter tersebut dapat juga didukung oleh satuan kwantitatif lain, misalnya unit. Penyusunan rencana kerja dalam satuan moneter tersebut, bertujuan untuk mempermudah membaca dan usaha untuk mengerti rencana tersebut. Rencana kerja yang diwujudkan di dalam suatu cerita panjang akan menyulitkan anggota organisasi untuk membaca atau mengerti. Karena itu, sebaiknya anggaran disusun dalam bentuk kwantitatif moneter yang ringkas.

2. Umumnya mencakup kurun waktu satu tahun.

Bukan berarti anggaran tidak dapat disusun untuk kurun waktu lebih pendek, tiga bulanan misalnya atau untuk kurun waktu lebih panjang, seperti lima tahunan. Batasan waktu di dalam penyusunan anggaran akan berfungsi untuk memberikan batasan rencana kerja tersebut.

3. Mengandung komitmen manajemen

Anggaran harus disertai dengan upaya pihak manajemen dan seluruh anggota organisasi untuk mencapai apa yang telah ditetapkan. Tanpa upaya serius dari pihak manajemen untuk mencapainya maka penyusunan anggaran tidak akan banyak manfaatnya bagi perusahaan. Karena itu, di dalam menyusun anggaran perusahaan harus mempertimbangkan dengan teliti sumber daya yang dimiliki perusahaan untuk menjamin bahwa anggaran yang disusun adalah realistis.

4. Usulan anggaran disetujui oleh pejabat yang lebih tinggi dari pelaksana anggaran. Anggaran tidak dapat disusun sendiri-sendiri oleh setiap bagian organisasi tanpa persetujuan dari atasan pihak penyusun. 
5. Setelah disetujui anggaran hanya diubah jika ada keadaan khusus. Jadi, tidak setiap saat dan dalam segala keadaan anggaran boleh diubah oleh manajemen. Anggaran boleh diubah jika situasi internal dan eksternal organisasi memaksa untuk mengubah anggaran tersebut. Perubahan asumsi internal dan eksternal memaksa untuk mengubah anggaran karena jika dipertahankan malah membuat anggaran tidak relevan lagi dengan situasi yang ada.

6. Jika terjadi penyimpangan/varians didalam pelaksanaannya, harus dianalisis sebab terjadinya penyimpangan tersebut. Karena, tanpa ada analisis yang lebih mendalam tentang penyimpangan tersebut maka potensi untuk terulang lagi di masa mendatang menjadi besar. Tujuan analisis penyimpangan tersebut adalah untuk mencari penyebab penyimpangan, supaya tidak terulang lagi di masa mendatang dan agar penyususnan anggaran dikemudian hari menjadi lebih relevan dengan situasi yang ada.

Terdapat beberapa tujuan disusunnya anggaran, antara lain:

1. Digunakan sebagai landasan yuridis formal dalam memilih sumber dan investasi dana.

2. Mengadakan pembatasan jumlah dana yang dicari dan digunakan

3. Merinci jenis sumber dana yang dicari maupun jenis investasi dana, sehingga dapat mempermudah pengawasan.

4. Merasionalkan sumber dan investasi dana agar dapat mencapai hasil yang maksimal.

5. Menyempurnakan rencana yang telah disusun karena dengan anggaran menjadi lebih jelas dan nyata terlihat.

6. Menampung dan menganalisis serta memutuskan setiap usulan yang berkaitan dengan keuangan.

\section{PENELITIAN TERDAHULU}

Menurut Diana (2015) menunjukkan bahwa konsistensi antar dokumen perencanaan dan penganggaran penting diperhatikan karena merupakan indikator dalam menilai kinerja pemerintah daerah. Hal ini sangat berpengaruh terhadap capaian dari visi, misi, tujuan, sasaran dan kebijakan yang telah direncanakan dalam dokumen perencanaan serta memiliki peran penting dalam pelaksanaan pembangunan untuk memperbaiki kesejahteraan masyarakat melalui program-program yang bertujuan untuk meningkatkan kualitas sumberdaya manusia seperti pendidikan dan kesehatan. Diana Novita (2015) dalam penelitiannya yang berjudul 
analisis konsistensi perencanaan dan penganggaran bidang pendidikan di Kabupaten Sumba Timur, hasil penelitian menunjukkan bahwa tingkat konsistensi perencanaan dan penganggaran di bidang pendidikan di Kabupaten Sumba cukup baik, adanya ketidakkonsistenan terjadi dikarenakan adanya keterlambatan informasi dana baik dari pemerintah provinsi maupun pusat yang wajib diakomodir oleh pemerintah daerah.

Ferdinandus (2015) melakukan penelitian mengenai analisis konsistensi perencanaan dan penganggaran daerah menemukan bahwa terdapat inkonsistensi yang menguatkan isu bahwa Kabupaten Lembata masih belum menjalankan pelayanan publik secara efektif dan efisien yang tercermin dari ketidakkonsistenan antara dokumen RPJMD-RKPD, RKPD-PPAS, RKPD-PPAS, PPAS-APBD. Hal ini karena tiga faktor utama yang paling berpengaruh terhadap inkonsistensi adalah: (1) terbatasnya teknologi dan informasi; (2) rendahnya komitmen pemimpin (Bupati); dan (3) kapasitas SDM aparatur yang masih rendah. ditambah "faktor lainnya" yang masih penuh dengan persoalan penyebab inkonsistensi yang dalam FGD dianggap sebagai persoalan mendasar.

Survival (2005) melakukan penelitian tentang analisis efisiensi dan efektivitas proses perencanaan dan penganggaran daerah menunjukkan bahwa terdapat beberapa inkonsistensi dalam proses perencanaan dan penganggaran daerah di Kota Malang dikarenakan keterbatasan anggaran sehingga banyak anggaran yang di pangkas di tingkat musrenbang yang lebih tinggi dan jika usulan anggaran tersebut di danai juga banyak yang tidak sesuai dengan realisasinya.

\section{METODOLOGI PENELITIAN}

Metode penelitian merupakan cara pemecahan masalah penelitian yang dilakukan secara terencana dan cermat untuk memahami dan mendalami objek yang menjadi sasaran.Salah satu metode yang dapat digunakan untuk penelitian adalah studi deskriptif. Metode penelitian yang digunakan dalam penelitian ini adalah metode deskriptif komparatif dengan menggunakan pendekatan kualitatif. Penelitian komparatif adalah penelitian yang membandingkan keberadaan satu variabel atau lebih pada dua atau lebih sampel yang berbeda (Sugiyono, 2012)

Dalam hal ini, membandingkan membandingkan penganggaran dan perencanaan antara dinas pendidikan di Kabupaten Bandung dan dinas Pendidikan Kabupaten Bogor. 


\section{ANALISIS DAN PEMBAHASAN}

Pada kenyataannya pelaksanaan perencanaan anggaran berbasis kinerja yang diamanatkan pemerintah tidak semudah dengan yang diharapkan. Masih terdapat banyak permasalahan dalam implementasinya sehingga kurangnya pencapaian output dan efek dari suatu program yang telah direncanakan misalnya adanya perencanaan kegiatan yang tidak sesuai dengan kebutuhan, kemudian ketidaksesuaian antara rencana anggaran biaya dengan satuan biaya sehingga menyebabkan adanya kelebihan dana (selisih dana yang tidak terserap) atau kekurangan dana yang dapat menghambat terealisasinya program tersebut.

Inkonsistensi tersebut merupakan indikator untuk menilai apakah kinerja pemerintah sudah berjalan dengan baik atau sudah sesuai dengan tujuan yang diharapkan atau belum. Semakin tinggi realisasi target menggambarkan bahwa tingkat pencapaiannya juga semakin baik. Secara lebih lanjut inkonsistensi yang terjadi antara satu dokumen dengan dokumen yang lain (dalam paper ini antara RENSTRA dan RENJA) yang terjadi di dinas pendidikan Kabupaten Bogor dan dinas Pendidikan Kabupaten Bandung dapat dilihat dari Tabel 2 dan 3 di bawah ini.

Tabel 2. Rencana Program dan Anggaran dalam RENSTRA Kab Bogor 2013-2018

\begin{tabular}{|c|c|c|c|c|c|c|}
\hline \multirow[b]{2}{*}{ Program } & \multicolumn{2}{|c|}{2013} & \multicolumn{2}{|l|}{2014} & \multicolumn{2}{|c|}{2015} \\
\hline & Pagu Anggaran & $\begin{array}{c}\text { Jml } \\
\text { Program }\end{array}$ & Pagu Anggaran & $\begin{array}{c}\text { Jml } \\
\text { Program }\end{array}$ & Pagu Anggaran & $\begin{array}{c}\text { Jml } \\
\text { Program }\end{array}$ \\
\hline $\begin{array}{l}\text { Pendidikan Dasar } \\
9 \text { tahun }\end{array}$ & 533.976 .943 .000 & 71 & 702.944 .930 .000 & 71 & 768.989 .438 .485 & 71 \\
\hline $\begin{array}{l}\text { Pendidikan } \\
\text { Menengah }\end{array}$ & 60.959 .752 .000 & 56 & 101.375 .392 .000 & 56 & 186.777.994.010 & 56 \\
\hline
\end{tabular}

Sumber : Renstra Dikbud Kab Bogor 2013-2018

Tabel 3. Rencana Program dan Anggaran dalam RENJA Kab Bogor 2013-2015

\begin{tabular}{|c|c|c|c|c|c|c|}
\hline \multirow[b]{2}{*}{ Program } & \multicolumn{2}{|l|}{2013} & \multicolumn{2}{|l|}{2014} & \multicolumn{2}{|l|}{2015} \\
\hline & Pagu Anggaran & $\begin{array}{c}\text { Jml } \\
\text { Program }\end{array}$ & Pagu Anggaran & $\begin{array}{c}\text { Jml } \\
\text { Program }\end{array}$ & Pagu Anggaran & $\begin{array}{c}\text { Jml } \\
\text { Program }\end{array}$ \\
\hline $\begin{array}{l}\text { Pendidikan Dasar } \\
9 \text { tahun }\end{array}$ & 389.571 .188 .379 & 51 & 320.956 .068 .650 & 43 & 288.408 .592 .084 & 43 \\
\hline
\end{tabular}


Bayu Kharisma. Perencanaan, Penganggaran dan Capaian Target Program Wajib Belajar 12...

\begin{tabular}{ccccccc}
$\begin{array}{c}\text { Pendidikan } \\
\text { Menengah }\end{array}$ & 137.195 .858 .921 & 33 & 113.807 .256 .790 & 37 & 165.091 .366 .491 & 37 \\
\hline
\end{tabular}

Sumber : Lakip Kab Bogor 2013-2015

Pada Tabel 2 dan 3 diatas, dapat dilihat bahwa terjadi inkonsistensi antara program yang direncanakan pada rencana strategis dan rencana tahunan dinas pendidikan Kabupaten Bogor. Pada RENSTRA, jumlah program pendidikan dasar 9 tahun sebanyak 71 program kemudian menurun pada RENJA menjadi sekitar 40-50an, sedangkan jumlah program pendidikan menengah menurun dari 56 program menjadi kurang dari 40 program. Begitupula dengan rencana anggaran dalam RENJA untuk pendidikan dasar 9 tahun lebih kecil dari RENSTRA, sedangkan rencana anggaran pada RENJA untuk pendidikan menengah pada tahun 2013-2014 lebih besar dari RENSTRA dan pada tahun 2015 justru lebih besar dari rencana anggaran pada RENSTRA. Hal ini bisa disebabkan oleh berbagai faktor, dan menurut penulis, faktor yang paling utama dalam menyebabkan terjadinya inkonsistensi yaitu kurangnya perencanaan program dan anggaran yang baik, karena dalam menyusun rencana dan anggaran itu dibutuhkan tenaga yang professional yang mengetahui betul tentang kondisi fisik, ekonomi dan lingkungan yang menjadi tujuan pembangunan itu sendiri.

Kondisi tersebut diprediksikan cukup sulit, mengingat situasi ekonomi yang dinamis sedangkan anggaran yang ada terbatas, terkadang pemerintah menyusun banyak sekali program sehingga terjadinya overlapping kemudian pada saat dianalisis kebutuhannya, perencanaan tersebut kurang sesuai sehingga pada akhirnya perencanaan yang sudah disusun berubah kembali dan kemudian hanya menyusun program prioritas saja. Bahkan setelah disusun program prioritas pun realisasinya masih belum maksimal karena kurangnya informasi dan penganggaran yang meleset, contohnya pada laporan kinerja kabupaten Bogor disebutkan bahwa banyak kegiatan yang pagu anggarannya kecil tetapi ketika diakumulasi secara keseluruhan jumlahnya menjadi besar karena adanya penawaran harga yang tidak sesuai dengan yang diterapkan oleh tim apresial.

Tabel 4. Rencana Program dan Anggaran dalam RENJA Kab Bandung 2013-2018

\begin{tabular}{ccccccc}
\hline \multirow{2}{*}{ Program } & \multicolumn{2}{c}{$\mathbf{2 0 1 3}$} & \multicolumn{2}{c}{$\mathbf{2 0 1 4}$} & $\mathbf{2 0 1 5}$ & Jml \\
\cline { 2 - 7 } & Pagu Anggaran & $\begin{array}{c}\text { Jml } \\
\text { Program }\end{array}$ & Pagu Anggaran & $\begin{array}{c}\text { Jml } \\
\text { Program }\end{array}$ & Pagu Anggaran & $\begin{array}{c}\text { Jml } \\
\text { Program }\end{array}$ \\
\hline $\begin{array}{c}\text { Pendidikan Dasar } \\
\text { 9 tahun }\end{array}$ & 143.846 .310 .507 & 43 & 73.336 .079 .850 & 47 & 73.336 .079 .850 & 39 \\
\hline $\begin{array}{c}\text { Pendidikan } \\
\text { Menengah }\end{array}$ & 79.069 .989 .243 & 22 & 69.261 .553 .122 & 26 & 72.261 .553 .122 & 26 \\
\hline
\end{tabular}

Sumber : Evaluasi hasil RPJMD Kab bandung 2010-2015 
Tabel 5. Rencana Program dan Anggaran dalam RENSTRA Kab Bandung 2013-2018

\begin{tabular}{|c|c|c|c|c|c|c|}
\hline \multirow[b]{2}{*}{ Program } & \multicolumn{2}{|l|}{2013} & \multicolumn{2}{|c|}{2014} & \multicolumn{2}{|l|}{2015} \\
\hline & Pagu Anggaran & $\begin{array}{c}\text { Jml } \\
\text { Program }\end{array}$ & Pagu Anggaran & $\begin{array}{c}\text { Jml } \\
\text { Program }\end{array}$ & Pagu Anggaran & $\begin{array}{c}\text { Jml } \\
\text { Program }\end{array}$ \\
\hline $\begin{array}{c}\text { Pendidikan Dasar } \\
9 \text { tahun }\end{array}$ & $153,744,422,993$ & 82 & $171,228,502,164$ & 82 & $1,317,747,108,000$ & 82 \\
\hline $\begin{array}{l}\text { Pendidikan } \\
\text { Menengah }\end{array}$ & $90,596,465,998$ & 56 & $107,018,703,326$ & 56 & $72,261,550,000$ & 56 \\
\hline
\end{tabular}

Sumber : Renstra Kab Bandung 2010-2015

Hal yang sama terjadi juga pada dinas pendidikan Kabupaten Bogor dimana adanya inkonsistensi antara rencana anggaran dan program pada dokumen RENSTRA dan dokumen RENJA. Pada dokumen renja terjadi penurunan jumlah program yang tadinya program pendidikan dasar 9 tahun berjumlah 82 pada RENSTRA menjadi sekitar 39-47 pada RENJA kemudian untuk program pendidikan menengah yang tadinya berjumlah 56 pada RENSTRA menjadi 22-26 program pada RENJA.

Selanjutnya, terjadi lonjakan yang sangat besar pada target anggaran RENSTRA program pendidikan dasar 9 tahun pada 2015 sehingga selisihnya dengan target anggaran pada RENJA sangat jauh. Hal ini juga mencerminkan bahwa banyaknya rencana program yang tidak sesuai dengan kebutuhan tetapi disusun dalam RENSTRA dan pada akhirnya menciptakan inkonsistensi perencanaan program tahunan. Perencanaan dan penganggaran yang telah disusun tentunya berpengaruh terhadap capaian dari tujuan, untuk menilai sejau mana evaluasi kinerja dinas pendidikan Kabupaten Bandung dan Kabupaten Bogor dalam mewujudkan program wajib belajar 12 tahun dengan indikator APK, APM dan RRLS, dapat kita bandingkan pada Tabel 6 sampai dengan 9 di bawah ini.

Tabel 6. Target APM,APK dan RRLS Kabupaten Bogor 2013-2015 (\%)

\begin{tabular}{|c|c|c|c|c|c|c|c|c|c|}
\hline \multirow{2}{*}{ Indikator } & \multicolumn{3}{|c|}{2013} & \multicolumn{3}{|c|}{2014} & \multicolumn{3}{|c|}{2015} \\
\hline & SD/MI & SLTP/MTs & SMA/MA & SD/MI & SLTP/MTs & SMA/MA & SD/MI & SLTP/MTs & SMA/MA \\
\hline APK & 108,91 & 96,34 & 56,83 & 109,11 & 97,93 & 59,51 & 109,31 & 98,17 & 62,19 \\
\hline APM & 99,20 & 88,42 & 51,60 & 99,40 & 91,31 & 54,28 & 99,60 & 94,21 & 56,96 \\
\hline RRLS & & 8,21 & & & 8,38 & & & 8,55 & \\
\hline
\end{tabular}


Bayu Kharisma. Perencanaan, Penganggaran dan Capaian Target Program Wajib Belajar 12...

Tabel 7. Realisasi APM,APK dan RRLS Kabupaten Bogor 2013-2015 (\%)

\begin{tabular}{|c|c|c|c|c|c|c|c|c|c|}
\hline \multirow{2}{*}{ Indikator } & \multicolumn{3}{|c|}{2013} & \multicolumn{3}{|c|}{2014} & \multicolumn{3}{|c|}{2015} \\
\hline & SD/MI & SLTP/MTs & SMA/MA & SD/MI & SLTP/MTs & SMA/MA & SD/MI & SLTP/MTs & SMA/MA \\
\hline APK & 104,47 & 89,19 & 48,96 & 109,34 & 93,94 & 50,32 & 110,56 & 97,25 & 57,09 \\
\hline APM & 96,22 & 63,56 & 33,80 & 96,24 & 77,04 & 39,76 & 95,82 & 78,52 & 45,11 \\
\hline RRLS & & 8,01 & & & 7,74 & & & 7,75 & \\
\hline
\end{tabular}

Sumber : Kemendikbud 2013-2015, BPS

Tabel 8. Target APM,APK dan RRLS Kabupaten Bandung 2013-2015 (\%)

\begin{tabular}{cccccccccc}
\hline \multirow{2}{*}{ Indikator } & \multicolumn{3}{c}{$\mathbf{2 0 1 3}$} & \multicolumn{3}{c}{$\mathbf{2 0 1 4}$} & \multicolumn{3}{c}{$\mathbf{2 0 1 5}$} \\
\cline { 2 - 10 } APK & SD/MI & SLTP/MTs & SMA/MA & SD/MI & SLTP/MTs & SMA/MA & SD/MI & SLTP/MTs & SMA/MA \\
\hline APM & 99,63 & 91,59 & 54,69 & 104,49 & 91,60 & 55,13 & 104,58 & 91,61 & 55,68 \\
\hline RRLS & 82,08 & 41,94 & 99,65 & 82,53 & 42,25 & 99,67 & 83,06 & 42,65 \\
\hline
\end{tabular}

Sumber : Renstra Dikbud Kab. Bandung 2010-2015, BPS

Tabel 9. Realisasi APM,APK dan RRLS Kabupaten Bandung

\begin{tabular}{|c|c|c|c|c|c|c|c|c|c|}
\hline \multirow{2}{*}{ Indikator } & \multicolumn{3}{|c|}{2013} & \multicolumn{3}{|c|}{2014} & \multicolumn{3}{|c|}{2015} \\
\hline & SD/MI & SLTP/MTs & SMA/MA & SD/MI & SLTP/MTs & SMA/MA & SD/MI & SLTP/MTs & SMA/MA \\
\hline APK & 105,01 & 89,82 & 47,30 & 105,07 & 93,41 & 50,22 & 107,08 & 95,41 & 56,53 \\
\hline APM & 95,34 & 64,29 & 37,94 & 95,86 & 78,46 & 34,88 & 95,61 & 78,71 & 46,16 \\
\hline RRLS & & 8,49 & & & 8,34 & & & 8,41 & \\
\hline
\end{tabular}

Jika melihat perbandingan antara target APK, APM dan RRLS dengan realisasi APK, APM dan RRLS dinas pendidikan Kabupaten Bogor dan Kabupaten Bandung dari tahun 2013-2015 maka kita dapat menilai bahwa program wajib belajar 9 tahun saja belum mampu dirampungkan, hal ini dicerminkan dari rata-rata lama sekolah yang masih dibawah 9 tahun.

Selain itu, APK dan APM SMP juga belum mencapai 100\% sedangkan APK dan APM SD sudah rampung diatas $100 \%$ dan APK dan APM pendidikan menengah masih dibawah $60 \%$. Dengan demikian, dari ketiga indikator tersebut Kabupaten Bogor tidak satupun yang realisasinya di atas target ataupun memenuhi target sedangkan untuk kabupaten Bandung, ada indikator yang melebihi target yaitu APK SD dan SMP pada tahun 2014-2015 dan juga APK dan APM SMA pada tahun 2015. Hal ini membuktikan bahwa kinerja pencapaian program wajib belajar 12 tahun target rampung 2018 masih jauh dari yang diharapkan. Selanjutnya indikator lain yang berkaitan disajikan pada Tabel 10 dan 11 dibawah ini : 
Tabel 10. Indikator Kinerja Pendidikan Dasar Dinas Pendidikan Kabupaten Bogor 2013-2015

\begin{tabular}{|lcccccc|}
\hline \multicolumn{1}{c}{ Indikator Kinerja } & \multicolumn{5}{c}{ Target } & \multicolumn{2}{c|}{ Realisasi Capaian } \\
\hline Aspek Pelayanan Umum SD & 2013 & 2014 & 2015 & 2013 & 2014 & 2015 \\
\hline 1. Angka Partisipasi Sekolah thd penduduk usia 7-12 thn & & & & & & \\
\hline 2. Angka Partisipasi Sekolah thd penduduk usia 13-15 thn & 1099,98 & 1002 & 1022 & 1026,19 & 882 & 858 \\
\hline 3. Rasio Ketersediaan SD-MI thd Penduduk usia 7-12 thn & 901,51 & 890 & 891 & 938,84 & 865 & 880 \\
\hline 4. Rasio Ketersediaan SMP-MTs thd Penduduk usia 13-15 th & 44,79 & 39 & 38 & 39,86 & 35 & 35 \\
\hline 5. Rasio Guru SD-MI/Murid & 33,67 & 31 & 30 & 31,04 & 29 & 29 \\
\hline 6. Rasio Guru SMP-MTs/Murid & 272,35 & 382 & 383 & 380,61 & 396 & 392 \\
\hline 7. Rasio Rombel/Guru SD-MI & 200,65 & 374 & 376 & 370,54 & 373 & 363 \\
\hline 8. Sekolah Pendidikan SD Kondisi Bangunan Baik & 1,09 & 0,88 & 0,91 & 0,85 & 0,81 & 0,91 \\
\hline 9. Sekolah Pendidikan SMP Kondisi Bangunan Baik & 89,85 & 59,03 & 61,05 & 57,05 & 59,43 & 61,46 \\
\hline 10. Angka Kelulusan (AL) SD/MI & 95,09 & 65,98 & 67,98 & 63,98 & 65,46 & 68,13 \\
\hline 11. Angka Kelulusan (AL( SMP/MTs & 99,21 & 99.85 & 99.89 & 99,81 & 100 & 99.73 \\
\hline 12. Angka Melanjutkan (AM) dari SD/MI ke SMP/MTs & 96,90 & 100 & 100 & 99,99 & 98.93 & 100 \\
\hline
\end{tabular}

Sumber : LAKIP Kab. Bogor

Tabel 11 Indikator Kinerja Pendidikan Menengah Dinas Pendidikan Kabupaten Bogor

\begin{tabular}{|lcccccc|}
\multicolumn{1}{c}{ Indikator Kinerja } & \multicolumn{7}{c}{ Target } & \multicolumn{3}{c|}{ Realisasi Capaian } \\
& 2013 & 2014 & 2015 & 2013 & 2014 & 2015 \\
\hline Pendidikan Menengah & & & & & & \\
\hline 1. Angka Partisipasi Sekolah thd penduduk usia 16-18 thn & 389,71 & 521 & 524 & 518,29 & 502 & 544 \\
\hline 2. Rasio ketersediaan SMA/SMK/MA thd pend usia 16-18 th & 18,15 & 20 & - & 19,24 & 19 & - \\
\hline 3. Rasio Guru SMA-SMK-MA/Murid & 270,54 & 373 & 375 & 369,49 & 370 & 344 \\
\hline 4. Sekolah pend. SMP/MTs \& SMA-SMK kondisi bangunan baik & 95,28 & 73,18 & 73,18 & 71,18 & 71,84 & 71,84 \\
\hline 5. Angka Putus Sekolah SMA/SMK/MA & 0,520 & 0,665 & 0,561 & 0,769 & 0,576 & 0,35 \\
\hline 6. Angka Kelulusan (AL) SMA/SMK/MA & 97,99 & 100 & 100 & 99,97 & 100 & 100 \\
\hline 7. Angka melanjutkan (AM) dari SMP/MTs ke SMA/SMK/MA & 69,67 & 81,44 & 83,44 & 79,44 & 81,67 & 93,44 \\
\hline Peningkatan Mutu Pendidik dan Tenaga Kependidikan & & & & & & \\
\hline 1. Guru yg memenuhi kualifikasi S1/D-IV & 55,94 & 72,92 & 77,48 & 68,86 & 71,54 & 74,43 \\
\hline
\end{tabular}

Sumber : LAKIP Kab. Bogor

Jika memperhatikan Tabel 11 di atas, ada beberapa indikator yang realisasi kinerjanya terus menurun dan dibawah target, indikator tersebut adalah APS usia 7-12 dan rasio ketersediaan, sedangkan beberapa indikator naik turun adalah APS 13-15, rasio guru, dan rasio rombel. Sedangkan indikator lainnya cenderung meningkat. Kemudian pada program pendidikan menengah, indikator kinerja cenderung naik turun tetapi ada kenaikan signifikan pada angka melanjutkan SMP ke SMA yang pada tahun 2015 mencapai 93.44\%. meskipun begitu, indikator lainnya tetap masih dibawah rata-rata sehingga pemerintah kabupaten Bogor harus tetap meningkatkan kinerjanya dalam mengoptimalkan program pendidikan menengah. 
Secara keseluruhan, program wajar 9 tahun mengalami penurunan capaian sedangkan capaian program pendidikan menengah sempat turun di tahun 2014 kemudian naik lagi di tahun 2015. Padahal anggaran pemerintah untuk program wajib belajar 9 tahun lebih besar dibandingkan dengan program pendidikan menengah. Hal ini berarti membuktinya adanya ketidaksingkronan antara kenaikan rencana anggaran dengan pencapaian kinerja dari rencana anggaran itu sendiri dan hal ini merupakan sebab akibat dari adanya inkonsistensi antara perencanaan dan anggaran sehingga realisasinya menjadi tidak efektif dan efisien. Jika program wajib belajar 9 tahun saja belum rampung maka pencapaian program wajib belajar 12 tahun masih jauh dari yang diharapkan. Lain hal nya dengan dinas pendidikan Kabupaten Bandung, pada LAKIP Kabupaten Bandung, tidak disediakan data lengkap mengenai indikator kinerja program pendidikan dasar dan pendidikan menengah, jadi dinas pendidikan kabupaten Bandung hanya mencantumkan indikator kinerja sasaran yang berkaitan dengan pencanangan wajib belajar 12 tahun sebagaimana disajikan pada Tabel 12 sebagai berikut.

\section{Tabel 12. Indikator Kinerja Program Pendidikan Dasar dan Menengah Dinas}

\section{Pendidikan Kabupaten Bandung}

\begin{tabular}{|c|c|c|c|c|c|c|}
\hline \multirow{2}{*}{ Indikator Kinerja } & \multicolumn{3}{|c|}{ Realisasi Kinerja } & \multicolumn{3}{|c|}{ Uraian Kinerja Tahun 2014} \\
\hline & 2011 & 2012 & 2013 & Target & Realisasi & $\%$ \\
\hline \% guru berpendidikan min s1/D4 & 71,5 & 72,81 & 78,25 & 78,5 & 86,17 & 109,77 \\
\hline AMH & 98,48 & 98,48 & 98,76 & 98,86 & 98,86 & 100 \\
\hline RLS & 8,62 & 8,67 & 8,72 & 8,71 & 8,72 & 100,11 \\
\hline APM SD & 99,57 & 99,59 & 99,59 & 99,65 & 95,13 & 95,46 \\
\hline APM SMP & 81,22 & 81,44 & 81,6 & 82 & 82,83 & 101,01 \\
\hline APM SMA & 41,5 & 41,84 & 42,94 & 42 & 37,96 & 88,10 \\
\hline Rata-rata kinerja capaian & 52,21 & 54,23 & 53,19 & & 53,12 & 102,57 \\
\hline
\end{tabular}

Sumber : LAKIP Kab. Bandung 2012-2014

Dengan keterbatasan data berdasarkan publikasi LAKIP Kabupaten Bandung, maka capaian kinerja secara keseluruhan yaitu berkisar lebih dari 50\%. Sehingga dapat disimpulkan bahwa Program Wajib Belajar dinas pendidikan Kabupaten Bandung belum bahkan bisa dikatakan masih jauh dari target yang diharapkan.

\section{REFERENSI}

Darlina, Meri dkk. (2016). Analisis Perecanaan dan Penganggaran Pada Dinas Pendidikan Provinsi Jambi. Jurnal Perspektif Pembiayaan dan Pembangunan Daerah Vol. 3 No 4, AprJun 2016 Hal 257-268. FEB Universitas Jambi 
Ferdinandus Diri Burin, dkk. (2015). Analisis Konsistensi Perencanaan Dan Penganggaran Daerah. Jurnal Ekonomika-Bisnis Vol. 6 No. 2, Juli 2015 Hal 177-188

Haryanto. (2008) .Perencanaan dan Penganggaran Daerah Pendekatan Kinerja Edisi Pertama.Semarang : Universitas Diponegoro

Husin, Muhammad. (2010). Penuntasan Wajib Belajar 12 Tahun di Provinsi DKI Jakarta. Jurnal Pendidikan dan Kebudayaan. Vol 16 Nomor 1 Hal 92-101. SMA Negeri Jakarta

LAKIP Kabupaten Bandung

LAKIP Kabupaten Bogor

Mardiasmo. 2002. Otonomi dan Manajemen Keuangan Daerah. Yogyakarta: Andi

Nafarin, M. (2004). Penganggaran Perusahaan. Jakarta: Penerbit Salemba Empat.

Novita, Diana. (2015). Analisis Konsistensi Perencanaan dan Penganggaran Bidang Pendidikan di Kabupaten Sumba Timur. Tugas Akhir Program Magister. Jakarta : Universitas Terbuka Jakarta

Osrinda, N dan Delis, A (2016). Analisis Konsistensi Perencanaan dan Penganggaran Serta Implikasinya terhadap Capaian Target Kinerja pada Badan Perencanaan Pembangunan Daerah Kabupaten Merangin. Jurnal Perspektif Pembiayaan dan Pembangunan Daerah Vol. 3 No. 3, Jan-Mar 2016 hal 151-162. Universitas Jambi

Rencana Kerja Dinas Pendidikan Kabupaten Bandung

Rencana Kerja Dinas Pendidikan Kabupaten Bogor

RPJMD Kabupaten Bogor Tahun 2013-2018 RPJMD

Kabupaten Bandung Tahun 2010-2015

Rencana strategis Kabupaten Bandung 2010-2015, 2016-2021 Rencana strategis Kabupaten Bogor 2013-2018

Rusdianto, (2006), Akuntansi Manajemen: Informasi Untuk Pengambilan Keputusan Manajemen, Penerbit PT Gramedia Widia Sarana Indonesia, Jakarta

Sugiarto, A dan Mutiarin, A. 2015. Konsistensi Prencanaan Pembangunan Daerah dengan Anggaran Daerah.Prosiding Interdiciplinary Post Graduate Student Conference.Yogyakarta : Universitas Muhammadiyah

Sugiyono (2012). “Metode Penelitian Kuantitatif Kualitatif dan R\&D”. Bandung: Alfabeta. 
Bayu Kharisma. Perencanaan, Penganggaran dan Capaian Target Program Wajib Belajar 12...

Survival. (2007). Analisis Efisiensi dan Efektivitas Proses Perencanaan dan Penganggaran Daerah. Jurnal Manajemen Akuntansi dan Bisnis - Fakultas Ekonomi Universitas Widyagama Malang, Volume 5 Nomor 3 Desember 2007, Hal. 453-466.

UU No 1 Tahun 2004

UU No 25 Tahun 2004 